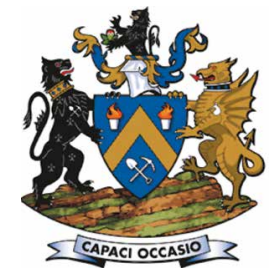

Affiliation:

1 University of Botswana,

Gaborone, Botswana.

Correspondence to:

K. Fichani

Email:

kfichani@hotmail.com

Dates:

Received: 11 Jan. 2019

Revised: 10 May 2019

Accepted: 17 May 2019

Published: October 2019

\section{How to cite:}

K. Fichani and M. Masialeti

Prospects for value addition in

copper in the emerging Kalahari

Copper Belt of Botswana.

The Southern African Insitute of

Mining and Metallurgy

DOI ID:

http://dx.doi.org/10.17159/24119717/570/2019

ORCiD ID

K. Fichani

https://orchid.org/0000-00019364-8217

\title{
Prospects for value addition in copper in the emerging Kalahari Copper Belt of Botswana
}

\author{
K. Fichani ${ }^{1}$ and M. Masialeti ${ }^{1}$
}

\begin{abstract}
Synopsis
The Kalahari Copper Belt (KCB), which stretches for about a $1000 \mathrm{~km}$ in northwestern Botswana, is emerging as a potential host to new copper and silver mining projects. Current resources are estimated at about $472 \mathrm{Mt}$ at grades ranging from $0.85 \%$ to $2.2 \%$ copper and 11 to $50 \mathrm{~g} / \mathrm{t}$ silver. In this paper, we constructed a discounted cash flow financial model of an Isasmelt technology copper smelter and sulphuric acid complex, and then used the model to determine the minimum economic size of a copper smelter and its attendant sulphuric acid plant in the $\mathrm{KCB}$, whether current and future production of copper concentrates would provide sufficient feed leading to satisfactory project economics for the smelter, and the level of imports of copper concentrates, if any, that would be required to ensure that the smelter operates at full capacity. The study concluded that the minimum economic size of the smelter would be $485 \mathrm{kt}$ per annum and that the projected tonnages of local copper concentrates would, on their own, fail to provide enough feed to the smelter. We recommend further work to more accurately define the likely production of copper concentrates from the KCB; the possibility of imports of copper concentrates; taxing the smelter at rates for manufacturing, which are currently $15 \%$ as opposed to the company tax rate of $22 \%$; and the possibility of negotiating lower electricity tariffs as this would lead to improved project economics for the smelter and sulphuric acid complex.
\end{abstract}

\section{Keywords}

copper value chain, Kalahari Copper Belt, project economics, copper smelter.

\section{Introduction}

The Kalahari Copper Belt (KCB) stretches for about $1000 \mathrm{~km}$ from south of Maun in Botswana through Ghanzi and into Namibia The estimated copper resources reported on the company websites of Khoemacau Copper mine (Cupric Canyon, 2018) and Tshukudu Metals' T3 project (Mod Resources, 2018) for their exploration projects amount to some $472 \mathrm{Mt}$ at grades varying from $0.852 .2 \%$ copper and 11-50 g/t silver. Two of the projects in the KCB with potential for developing into producing mines are Cupric Canyon's Khoemacau Zone 5 and Tshukudu Metals' T3 project. The Khoemacau Zone 5 project, currently at the mine development stage, has resources estimated at $100.3 \mathrm{Mt}$ at $1.95 \%$ copper and $20 \mathrm{~g} / \mathrm{t}$ silver. The Tshukudu Metals T3 project is at the full feasibility study stage and has resources of $60 \mathrm{Mt}$ at $0.98 \%$ copper and $14 \mathrm{~g} / \mathrm{t}$ silver. Cradle Arc plc, a majority owner of Mowana Copper Mine, some $100 \mathrm{~km}$ west of Francistown, reports on its website that the mine has copper resources of $72 \mathrm{Mt}$ at $1.5 \%$ copper and is currently producing about $12000 \mathrm{t}$ of copper in concentrate per annum (Cradle Arc plc, 2018). The two proposed projects are reported to have robust project economics with $\mathrm{C} 1$ cash costs net of silver credits of US\$1.00 per pound for Khoemacau Zone 5 and US\$1.22 per pound for the T3 project.

The mineralogy of the copper sulphide ores in the KCB consists of chalcocite, chalcopyrite, and bornite. The Khoemacau project will initially use the Boseto Copper processing plant, which is under care and maintenance, to produce copper and silver in concentrate for sale to regional and international copper smelters and refiners. The T3 project prefeasibility study indicates that while the concentrate to be produced will be relatively free of deleterious elements, there will be further investigations at the full feasibility study phase to lower the lead, arsenic, and bismuth contents to below smelter penalty levels (Mod Resources, 2018).

\section{Candidate smelting technologies}

Copper smelting technologies are well established, and the choice of technology is based mainly on capital and operating costs as well as the efficient capture of the sulphur dioxide gas to produce 


\section{Prospects for value addlition in copper in the emerging Kalahari Copper Belt of Botswana}

sulphuric acid. The global trend in growth in new copper smelter capacity has been based on two technologies - Outotec flash smelting, which includes flash smelting, flash converting, and direct-to-blister flash smelting; and top submerged lance or TSL, which includes Ausmelt and ISASMELT (Kojo, Scheidema, and Reuter, 2015). In the Southern African region, recent installation of copper smelters with sulphuric acid plants include the Mufulira smelter upgrade project in Zambia, where an ISASMELT furnace replaced an electric furnace in 2006, resulting in about a $40 \%$ reduction in operating costs (Barlows et al., 2012) and the Kansanshi smelter and sulphuric acid complex in 2015 (First Quantum Minerals Ltd, 2012). The advantages that have been cited by mines in Zambia for the selection of TSL over flash smelting technology include a smaller footprint, lower capital and operating costs, and ease of operation (Roos and de Vries, 2005; Barlows et al., 2012).

The process flow diagram for an ISASMELT copper smelter and acid plant is shown in Figure 1. In summary, the smelter would treat copper concentrates to produce copper anodes for refining in regional or overseas refineries to produce cathode copper and silver. The off-gas from the smelting furnace would be used to produce sulphuric acid, which has application in copper refining as well as the manufacture of fertilizers.

\section{Value addition drivers for copper}

Copper is traded internationally as concentrate, matte, blister, anode, or cathode copper. The factors that influence the level of value addition for a copper deposit are profitability, capacity utilization of the beneficiation facility, environmental compliance costs, proximity to semi-fabricators and downstream manufacturers of copper based products, supply and demand, as well as copper price volatility. The main factor that influences the decision to either sell concentrate or smelt on site is profitability; this is because mining provides the highest returns on investment as compared to smelting and refining. Low capacity utilization of existing smelters puts downward pressure on the treatment and refining charges, thus improving the net smelter returns to mining companies. On the other hand, environmental compliance costs for sulphur dioxide abatement are not only high, but would also require the construction of a sulphuric acid plant and tend to discourage the establishment of smelting and refining facilities on mining sites (World Bank, 2012). The location of copper concentrate smelting and refinery complexes is largely influenced by the existence, in close proximity, of semifabricators and other downstream manufacturers of copper-based products (World Bank, 2012). It is for this reason that most copper smelters and refiners are located in major industrialized regions of the world, such as in Asia (mainly China, Japan, South Korea, and South East Asia), Europe, and the USA (World Bank, 2011). A major technical advantage of this is that mill scrap generated during fabrication and other downstream processes can be recycled in the smelters.

The current global supply deficit for refined copper is likely to widen due to a variety of factors that may interrupt supply (Lee and Shin, 2018). For instance, the copper project pipeline fell by about $50 \%$ between 2011 and 2017 and there are no copper mining projects currently nearing production (Glasenberg, 2018). Other long-term supply challenges include the decline in production levels due to a variety of reasons, chief among which are the ageing of current major producing mines, declining grades, and closure at end of mine life (Glasenberg, 2018; Lee and Shin, 2018). The demand for copper is dominated by China, which is the world's largest importer of copper in intermediate products (Economic Research Institute, 2017) and in 2016 accounted for just over one-third of global copper smelter production (International Copper Study Group, 2018). It is projected that the supply-demand deficit for China will average some 4.5-5.5 Mt/a over the period 2020 to 2030 (Zhang et al., 2015). The key drivers of future demand for copper include the electric vehicle market, which some analyst project would contribute significantly to global demand. For instance, Lee and Shin 2018) forecast an annual growth rate of $22 \%$ until 2030 , at which time electric vehicles will make up some $8.2 \%$ of global demand for copper, while Glasenberg (2018) anticipates a 30\%

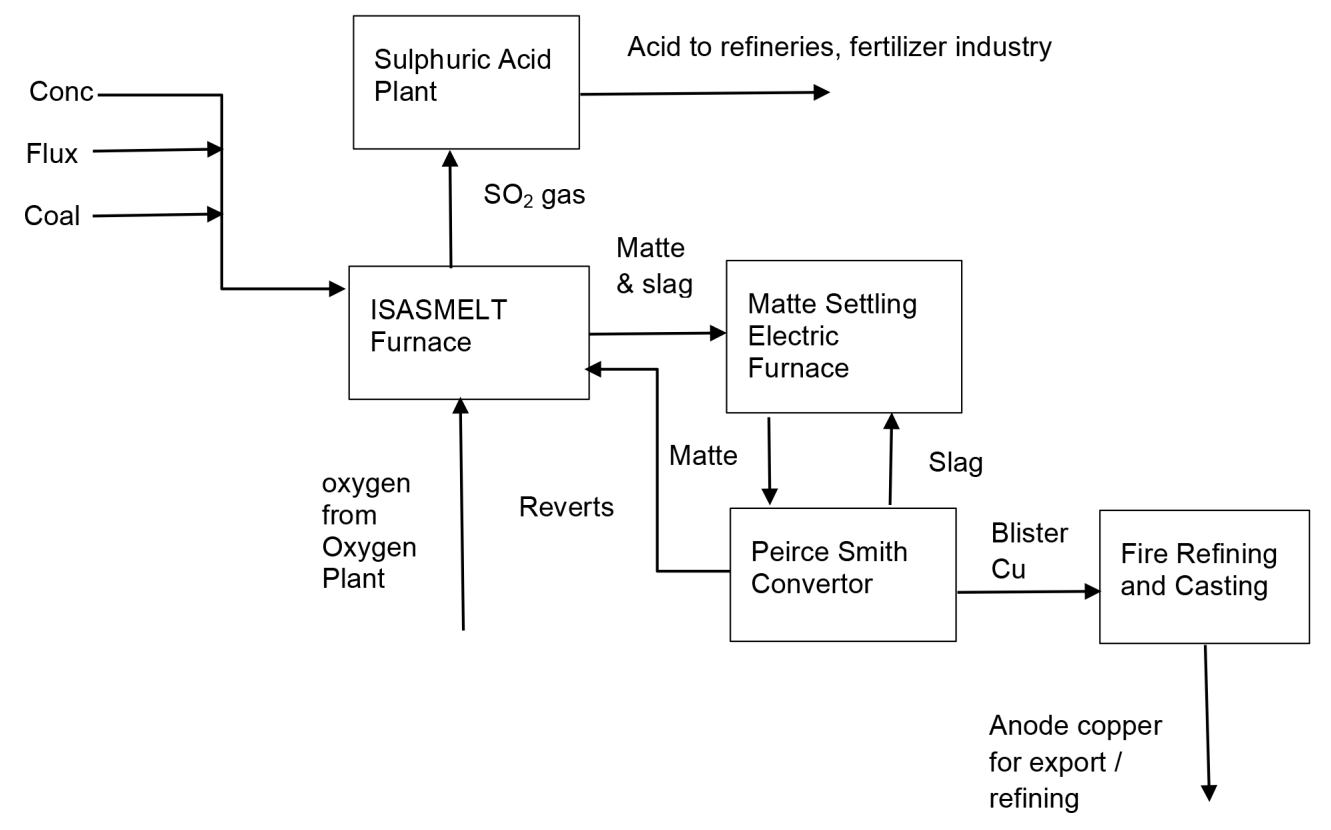

Figure 1-Process flow diagram of an ISASMELT copper smelter and acid plant (adapted from Roos and de Vries, 2005) 


\section{Prospects for value addition in copper in the emerging Kalahari Copper Belt of Botswana}

market share target for electric vehicles in 2030, resulting in an $18 \%$ increase over the 2017 global demand for copper.

Copper prices are fairly stable and are forecast to remain in a narrow trading band over the next five years (Lee and Shin, 2018). For instance, the World Bank forecasts nominal copper prices to be US $\$ 3.14$ per pound in 2025 , up only slightly from US $\$ 3.08$ per pound in 2018 , even though a deficit in supply is forecast. This should lessen the market risk faced by any new copper projects in the development pipeline.

Lessons from the Zambian copper sector, which has achieved beneficiation levels up to the production of refined copper, demonstrate that at the appropriate scale, copper beneficiation is profitable in landlocked mining countries. The challenge, it seems, is that of further value addition by way of fabrication and end-user products (Mulunda, Musonda, and Luwaya, 2015). In a related study, the major impediments to Zambia's progression into fabrication and end-user manufacturing were cited as the small size of the domestic and continental market, which is currently serviced by manufacturers in South Africa, and the inefficient transport system to export end-user products to the international markets (World Bank, 2011).

For the policy-maker, the mining sector presents opportunities for downstream economic linkages through mineral beneficiation. There is therefore great interest by policy-makers in Botswana to determine whether the existing and proposed copper and silver mining projects can sustain further beneficiation of copper beyond the production of concentrates, and what policy interventions, if any, would facilitate such activities. The other factors that have to be considered by the policy-maker are the challenges that a copper mine located in the KCB would face in getting its products to market due to the landlocked nature of the country, lack of rail infrastructure for exports of high volumes of concentrates, the attendant long distance to ports, as well as the long distances by sea to smelters in the Far East.

The KCB has huge reserves of copper and silver, and value addition along the copper value chain has the potential to go beyond the production of concentrate. The purpose of this research was to establish whether the projected tonnage of concentrates from projects at advanced stages of exploration and mine development in the KCB would justify the establishment of a custom copper smelter with a sulphuric acid plant.

\section{Material and methods}

The projected local concentrate production, revenues to the smelter in the form of treatment charges, and capital and operating costs of an ISASMELT technology-based smelter were used to develop a desktop financial model that was used to evaluate the likely profitability of a standalone smelter and sulphuric acid complex. This smelter complex could either operate on a full toll smelting basis or as a custom smelter, thus either purchasing concentrates outright or toll smelting for producers in the KCB and the region. A sulphuric acid plant was included in each case to ensure that the project would be environmentally compliant.

In order to develop a discounted cash flow financial model of the smelter and sulphuric acid complex, the data from $\mathrm{KCB}$ projects was used as input to the model. The data includes timing and production of concentrate, quality of concentrates, mineralogical composition of the concentrate, treatment charges, labour and power costs, and finally the capital costs of the smelter and sulphuric acid plant. An after-tax desktop financial evaluation of a standalone copper smelter to smelt copper concentrates from mines in the KCB and other parts of the country and (possibly) the region was developed.

\section{Data}

\section{Concentrate production and timing}

Data on planned concentrate production and the likely timing of such concentrates was obtained from the websites of companies involved in exploration for copper in the KCB. Data for concentrate production under two possible scenarios, the base and expansion cases, is presented in Tables I and II respectively.

It is apparent that the approach by the exploration companies is to start the mining projects to demonstrate the robustness of project economics, and then rely on this to raise capital for expanded production. This approach is taken as the most likely scenario regarding the development of the copper mining projects in the KCB. Table II presents the projected concentrate production under this most likely scenario of the expansion case.

\section{Spot treatment and refining charges}

The revenue stream to a copper smelter consists of treatment, refining, and penalty charges (TR/RC plus penalties), metal premiums, free metal, and by-products. These are presented in Table III together with their computation (New Boliden, 2017; Söderström, 2008). Typical net smelter return contract terms

Table I

Estimated production of copper concentrates from Botswana projects under the base case

\begin{tabular}{|l|c|c|c|c|c|c|c|c|c|c|}
\hline \multirow{2}{*}{ Year } & \multicolumn{10}{|c|}{ Production (kt) } \\
\cline { 2 - 12 } & $\mathbf{1}$ & $\mathbf{2}$ & $\mathbf{3}$ & $\mathbf{4}$ & $\mathbf{5}$ & $\mathbf{6}$ & $\mathbf{7}$ & $\mathbf{8 - 1 3}$ & $\mathbf{1 4}$ & $\mathbf{1 5 - 2 5}$ \\
\hline T3 open pit & 0 & 0 & 0 & 70 & 70 & 70 & 70 & 70 & 0 & 0 \\
\hline Zone 5 & 0 & 0 & 140 & 140 & 140 & 140 & 70 & 140 & 140 & 140 \\
\hline Mowana & 62 & 62 & 80 & 62 & 62 & 62 & 62 & 62 & 62 & 0 \\
\hline Total & 62 & 62 & 220 & 272 & 272 & 272 & 272 & 272 & 202 & 140 \\
\hline Grades & \multicolumn{10}{|c|}{} \\
\hline \% Cu (\%) & 34 & 34 & 39 & 38 & 38 & 38 & 38 & 38 & 38 & 42 \\
\hline Ag (oz/t) & 0 & 0 & 198 & 258 & 258 & 258 & 258 & 258 & 216 & 312 \\
\hline $\begin{array}{l}\text { Weighted average grades of total concentrates based on estimated mine production } \\
\text { from projects and information on company websites }\end{array}$
\end{tabular}

Table II

Estimated production of copper concentrates from Botswana projects under the expansion case

\begin{tabular}{|l|c|c|c|c|c|c|c|c|c|c|}
\hline \multirow{2}{*}{ Year } & \multicolumn{10}{|c|}{ Production (kt) } \\
\cline { 2 - 13 } & $\mathbf{1}$ & $\mathbf{2}$ & $\mathbf{3}$ & $\mathbf{4}$ & $\mathbf{5}$ & $\mathbf{6}$ & $\mathbf{7}$ & $\mathbf{8 - 1 3}$ & $\mathbf{1 4}$ & $\mathbf{1 5 - 2 5}$ \\
\hline T3 open pit & 0 & 0 & 0 & 70 & 70 & 70 & 93 & 93 & 0 & 0 \\
\hline Zone 5 & 0 & 0 & 140 & 140 & 140 & 140 & 70 & 233 & 233 & 233 \\
\hline Mowana & 62 & 62 & 80 & 62 & 62 & 62 & 62 & 62 & 62 & 0 \\
\hline Total & 62 & 62 & 220 & 272 & 272 & 272 & 295 & 388 & 295 & 233 \\
\hline Grades & \multicolumn{10}{|c|}{} \\
\hline Cu (\%) & 34 & 34 & 39 & 38 & 38 & 38 & 38 & 39 & 40 & 42 \\
\hline Ag (oz/t) & 0 & 0 & 198 & 258 & 258 & 258 & 258 & 278 & 246 & 312 \\
\hline $\begin{array}{l}\text { Weighted average grades of total concentrates based on estimated mine production } \\
\text { from projects and information on company websites }\end{array}$ \\
\hline
\end{tabular}




\section{Prospects for value addition in copper in the emerging Kalahari Copper Belt of Botswana}

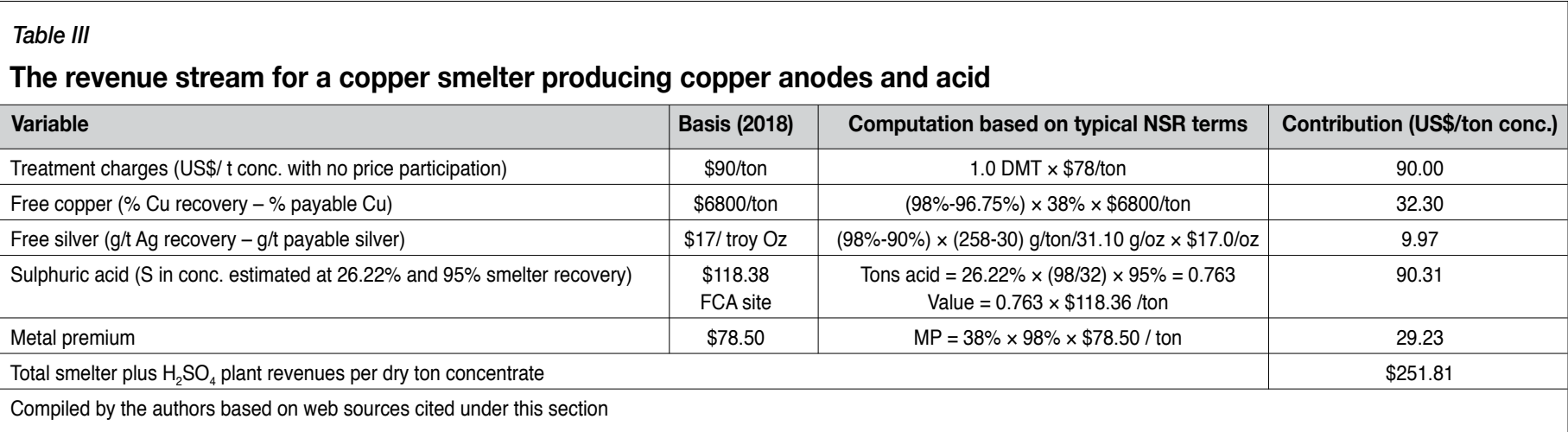

\section{Table IV}

\section{The estimated number of employees and annual cost of labour}

\begin{tabular}{|l|c|c|}
\hline Estimated number of workersa & Estimated monthly cash earnings for mining (US\$) ${ }^{b}$ & Estimated annual cash earnings (US\$) \\
\hline 600 & 1710.42 & 12315024 \\
\hline
\end{tabular}

a Based on the Kansanshi copper smelter and sulphuric acid project.

b The total monthly cash earnings in the mining and quarrying sector as at September 2017 was BWP 17666 . This is adjusted by a $3 \%$ inflation to BWP18 195.98 , which is equivalent to US $\$ 1710.42$ per month.

Table $V$

The annual cost of power

\begin{tabular}{|c|c|c|c|c|c|c|}
\hline $\begin{array}{l}\text { Electricity } \\
\text { (MWh/t anode) }\end{array}$ & $\begin{array}{l}\text { Est. Cu anode } \\
\text { (t) }\end{array}$ & $\begin{array}{l}\text { Annual MWh } \\
\text { consumed }\end{array}$ & $\begin{array}{c}\text { Estimated } \\
\text { demand (MW) }\end{array}$ & $\begin{array}{l}\text { Energy charge } \\
\text { (US\$/kWh) }^{\mathrm{b}}\end{array}$ & $\begin{array}{c}\text { Demand charge } \\
\text { (US\$/kW) }\end{array}$ & $\begin{array}{l}\text { Totsl est. energy and } \\
\text { demand charge (US\$) }\end{array}$ \\
\hline 1.39 & 185417 & 257730 & 29.42 & 0.06 & 17.45 & 21520823 \\
\hline
\end{tabular}

a Power consumption for Zambian smelters (Boulamanti and Moya, 2016).

b Botswana Power Corporation energy charge is BWP0.634 per kWh and demand charge is BWP185.6488 per kW. Exchange rate used is BWP1.0 Bz = US $\$ 0.094$.

were obtained from web sources (Connelly, 2017) together with spot values for treatment and refining charges for the years 2017 and 2018 (Leung, 2018), which were used to estimate the nominal treatment and refining charges (TR/RC) for the modelled smelter on the KCB. The Foskor chemical plant's product price for sulphuric acid, which is quoted as FCA Richards Bay or exworks, was used as acid buyers from the modelled smelter would similarly collect acid from the site (Foskor, 2018). Commodity price forecasts by the World Bank were used for copper and silver (World Bank, 2018).

\section{Operating costs - labour and power}

The approach adopted in estimating the operating cost is to use the unit costs of a comparable copper smelter in the region. The smelter selected is the Kansanshi copper smelter in Zambia, which is based on the ISASMELT technology and treats copper concentrates to produce copper anodes and sulphuric acid. The labour required to operate the smelter and acid plant complex is assumed to be independent of the capacity, and therefore data from a reference plant can be used, or if this is not available, it can be estimated from the productivity ratio and the anode capacity of the reference copper smelter. Once the number of employees has been estimated, the annual labour cost for the modelled smelter in Botswana is estimated by applying the average monthly wages in the mining and quarrying sector, which is found in the monthly 'Formal Sector Employment
Survey' by Statistics Botswana. The estimated labour requirement and annual cost for the smelter and acid plant complex is presented in Table IV.

The annual cost of power is based on the power consumption per ton of copper anode for the reference plant, but taking into account the specific tariffs applicable in Botswana. This is presented in Table $\mathrm{V}$.

\section{Indicative capital costs of a copper smelter and acid plant complex}

The capital costs of recent copper smelter projects were researched from web sources and the six-tenths rule was applied to estimate the capital cost for a given capacity of modelled smelter for the KCB. The Kansanshi copper smelter in the Zambian Copper belt, which was commissioned in 2015 with a smelting capacity of $1.2 \mathrm{Mt} / \mathrm{a}$ copper concentrate at $26 \%$ copper to produce 300000 t of copper anodes and $1 \mathrm{Mt}$ sulphuric acid, was used. The 2012 estimates at US\$635 million and US 20 cents per pound were used for the project capital cost and smelter costs respectively (First Quantum Minerals, 2012). More recent web reports indicated that the smelter and acid plant complex was constructed from early 2012 and commissioned in mid-2015 at a cost of US $\$ 900$ million. It is also reported that the smelter achieved a quick ramp-up to full production in just over five months (Kansanshi Mining, 2018). According to First Quantum's press release of 12 October 2013, the copper smelter project 


\section{Prospects for value addition in copper in the emerging Kalahari Copper Belt of Botswana}

capital cost was estimated at US\$690 million, implying that the acid plant capital cost would have been US\$210 million in 2014 . The six-tenths rule uses as a reference the copper smelter capital cost of US\$690 million and capacity of $1.2 \mathrm{Mt}$ concentrate per annum, and the sulphuric acid plant's capital cost of US\$210 million for a $1 \mathrm{Mt} / \mathrm{a}$ plant, to estimate the cost of an ISASMELT and sulphuric acid plant for the modelled smelter in the KCB. As the estimated capital costs are assumed to be for the year of commissioning, 2014, an escalation factor is applied using the Chemical Engineering Plant Cost Index (CEPCI). Table VI presents the estimated capital costs of the modelled KCB copper smelter and sulphuric acid plant based on a minimum economic size that would provide a real return of $8.0 \%$.

The six-tenths rule is a well-known method for estimating the capital cost of a plant given that of a similar, recently constructed plant using the same technology. The accuracy of such desktop study estimates is $-30 \%$ to $+50 \%$.

$$
C_{2}=C_{1} *\left(\frac{Q_{2}}{Q_{1}}\right)^{0.6} *\left(\frac{I_{t}}{I_{0}}\right)
$$

where

$C_{2}, Q_{2}=$ Cost and capacity of plant to be estimated, respectively

$C_{1}, Q_{1}=$ Cost and capacity of reference plant

$I_{t}=$ Cost index of the plant in year 2

$I_{o}=$ Cost index for the reference plant.

\section{Fiscal regime}

In terms of Schedule Twelve of the Income Tax Act of Botswana, a base metal mining project is taxed under a variable rate income tax formula (VRIT) in which the annual rate of tax is computed based on the profitability ratio of the project as follows:

$$
\text { Annual tax rate }=70-\left(\frac{1500}{X}\right)
$$

where $X=$ profitability ratio, defined as taxable income / gross income

The annual tax rate will be not less than the company tax rate, which is currently $22 \%$.

Other key aspects of the mining fiscal regime that would apply to the modelled KCB copper smelter are a $100 \%$ accelerated depreciation of capital with unlimited loss carry forward.

\section{The discounted cash flow financial model}

The model determines the minimum economic size of the smelter and sulphuric acid complex using goal seek. Two concentrate sourcing scenarios are modelled to determine the profitability of the smelter complex when treating only local concentrates and when supplementing any spare capacity with imported concentrates. The projected proportions of feed to the smelter are given in Table VII. These two concentrate sourcing scenarios are then evaluated under two fiscal regimes, the variable rate income $\operatorname{tax}$ (VRIT), which applies to base metals, and the lower taxation regime that applies to manufacturing businesses. Extending this lower taxation regime to the copper smelter and acid plant complex would improve the project economics for the copper concentrate producers. Other things being equal, this would also lead to higher tax revenue from the mining stage of the copper value chain, which would partly offset the foregone fiscal benefits from a lower tax rate.

The input variables that were used to run a discounted cash flow financial model for the KCB copper smelter and sulphuric acid complex are presented in Table VIII. The values are in constant 2018 money terms. The model assumed an 8\% real discount rate based on current mining industry practice.

\section{Results}

The project economics for a copper smelter with a capacity of 485 kt concentrate and $370 \mathrm{kt}$ acid per annum are presented in Table IX. The projected local copper concentrate supply would result in poor project economics, represented by scenario 1 . The real NPV (8\%) would be a negative US\$144.496 million; IRR would be $3.42 \%$, and the payback period 13 years. These poor project economics would not be enhanced significantly and would fail to turn positive under a low tax scenario, showing just a marginal improvement to NPV (8\%) of negative US\$48.471 million; an IRR of $6.5 \%$, and a real payback period of 12 years. Scenario 3 assumes that the smelter would be able to secure additional concentrates from the region, and this is the case that was used to determine the minimum size of the smelter and under the mining fiscal regime with VRIT, it gives an NPV (8\%) of zero; an IRR of $8 \%$ as expected, and a payback period of 10 years. Scenario 4 assumed that there would be a case for taxing the smelter as a manufacturing business. The real NPV (8\%) would be a positive US\$134.712 million; the IRR would be $11.03 \%$, and

\begin{tabular}{|c|c|c|c|c|c|c|c|c|c|c|}
\hline \multirow[b]{2}{*}{ Year } & \multicolumn{10}{|c|}{ Proportion of feed to the smelter (\%) } \\
\hline & 1 & 2 & 3 & 4 & 5 & 6 & 7 & 8-13 & 14 & $15-25$ \\
\hline Base case & & & 45 & 56 & 56 & 56 & 61 & 80 & 61 & 48 \\
\hline \multirow{2}{*}{$\begin{array}{l}\text { Base case } \\
+ \text { imports }\end{array}$} & Local & & 45 & 56 & 56 & 56 & 61 & 80 & 61 & 48 \\
\hline & Import & & 55 & 44 & 44 & 44 & 39 & 20 & 39 & 52 \\
\hline
\end{tabular}
the payback period 10 years.

The estimated capital cost for a copper smelter (minimum economic size) and acid plant in the KCB

\begin{tabular}{|l|c|c|c|}
\hline & Est. Cu conc. (Mt) & Capital cost in 2014 (US\$ million) & Equivalent cost in 2018 (US\$ million) \\
\cline { 2 - 4 } & & $\mathbf{2 0 1 4}$ & 690 \\
\hline Kansanshi smelter & 1.2 & 690 & 401.1 \\
\hline KCB smelter & 0.485 & 401.1 & 210 \\
\hline Kansanshi acid plant & 1.0 & 210 & 576.10 \\
\hline KCB acid plant & 0.370 & 115.8 & 576.40 \\
\hline
\end{tabular}




\section{Prospects for value addition in copper in the emerging Kalahari Copper Belt of Botswana}

Table VIII

Input variables for the KCB financial model

\begin{tabular}{|c|c|c|}
\hline & Calculation & Amount (US\$ million per annum) \\
\hline Revenue from treatment charges, free metal, and metal premium & 485000 t conc. $\times \$ 161.50$ per ton & 78.328 \\
\hline Revenue from acid sales & $485000 \mathrm{t}$ conc. $\times 0.763 \mathrm{t}$ acid per ton conc. $\times \$ 118.36$ per ton acid & 43.800 \\
\hline Total annual revenue & & 122.128 \\
\hline Annual labour operating costs & 600 workers $\times \$ 1710.42$ per worker $\times 12$ months & 12.315 \\
\hline Annual power costs & (see Table V) & 21.521 \\
\hline Total annual operating costs & & 33.836 \\
\hline Earnings before interest, taxes, depreciation and amortization & 88.292 & \\
\hline $\begin{array}{l}\text { Capital cost of smelter and sulphuric acid plant } \\
\text { (assume spent equally over } 24 \text { months) }\end{array}$ & (see Table VI) & 516.9 \\
\hline Allowance for maintenance & Assume $1 \%$ of capex & 5.169 \\
\hline
\end{tabular}

Table IX

Project economics for a $0.485 \mathrm{Mt} / \mathrm{a}$ concentrate KCB copper smelter and $0.370 \mathrm{Mt} / \mathrm{a}$ sulphuric acid complex

\begin{tabular}{|c|c|c|c|c|c|}
\hline \multirow[b]{2}{*}{ Tax and imports scenario } & \multicolumn{5}{|c|}{ Project economics in real 2018 money terms (US\$ million) } \\
\hline & NPV (5\%) & NPV (8\%) & NPV (10\%) & IRR (\%) & Payback (years) \\
\hline VRIT; no imports & $(61.2)$ & $(144.5)$ & $(182.4)$ & 3.42 & 13 \\
\hline Low tax; no imports & 61.4 & $(48.5)$ & $(98.2)$ & 6.50 & 12 \\
\hline VRIT; with imports & 132.4 & 0 & $(60.5)$ & 8.00 & 10 \\
\hline Low tax; with imports & 349.4 & 134.7 & 39.0 & 11.03 & 10 \\
\hline
\end{tabular}

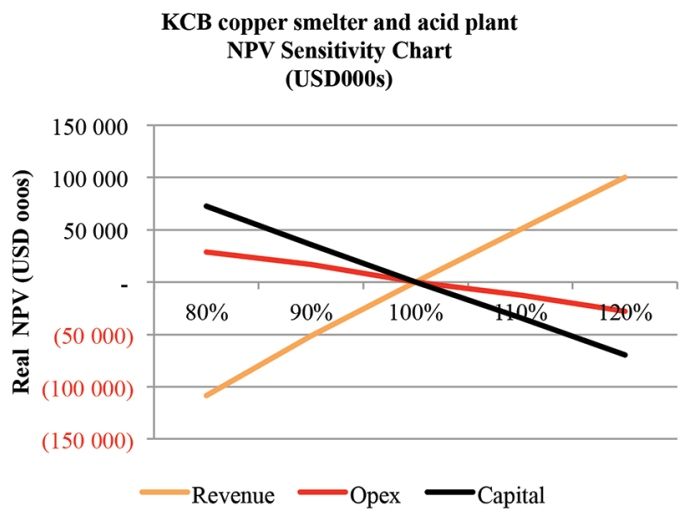

Figure 2-NPV sensitivity to capital, revenue, and operating costs

The NPV is most sensitive to revenues, followed by capital costs, and is least sensitive to operating costs (see Figure 2).

\section{Discussion}

The results of the model indicated that for the expanded production cases of the two projects, Cupric Canyon's Khoemacau project or Zone 5, which is at the mine development stage and Tshukudu Metals' T3 project, which is at the full feasibility study stage, the concentrate production is not sufficient to support a copper smelter and sulphuric acid plant for Botswana copper projects. Copper concentrates from these projects are destined for smelting in Chinese smelting and refining complexes, and they have to travel long distances by both land and sea to reach these smelters and refineries. If the full potential of the KCB becomes clearer with more detailed resource delineation that leads to development of more mines or expansion of capacity at existing mines, then the outlook for a local copper and sulphuric acid plant would be improved. It is important to realize that the sulphuric acid plant would not only be included to meet the environmental compliance requirements, but also to serve as a source of significant by-product revenues.

One of the factors in the establishment of the copper smelter and sulphuric acid plant would be the level of tax that would apply to it. The smelter and acid plant complex would clearly be a major industrial investment that the policy-maker could use to negotiate a tax agreement, as scenario 4 demonstrated that if the manufacturing tax rate of $15 \%$ is applied to the project, this would turn around the project economics from poor to satisfactory with a real NPV (8\%) of a positive US\$134.712 million; an IRR of $11.03 \%$, and a real payback period of 10 years. The potential benefits of taxing the smelter as a manufacturing business include the following.

- There would be an improvement in the net smelter returns to local producers of concentrate, which will not only enhance their profitability but also the life of their projects due to the increase in reserves that would result from reduced cut-off grades.

> There would be an improvement in tax revenues at the mining stage, which will slightly offset the foregone tax revenues from the copper smelter being taxed at a lower rate than the producers of copper concentrates.

- The production of sulphuric acid would provide the key ingredient in the production of fertilizers.

- Finally, the local production of acid would create opportunities for the exploitation of oxide and supergene copper sulphide ores through leaching, solvent extraction, and electrowinning, a process that is characterized by lower capital and operating costs than the pyrometallurgical route. 


\section{Prospects for value addition in copper in the emerging Kalahari Copper Belt of Botswana}

The economic viability of the copper smelter complex would also be driven by the electricity tariffs, as these have been found to make up approximately $30-35 \%$ of the operating costs (Boulamanti and Moya, 2016). The Botswana Power Corporation is currently expanding its grid into the $\mathrm{KCB}$ and there is therefore an expectation that tariffs will continue to rise, which would erode the project economics unless the smelter could negotiate sustainable rates for its business.

\section{Conclusion}

The purpose of this study was to establish whether the projected tonnage of locally produced copper concentrates from Mowana copper mine and from projects at advanced stages in exploration and mine development in the Kalahari Copper Belt of Botswana would justify the establishment of a copper smelter and a sulphuric acid plant in the KCB. The Kansanshi copper smelter and sulphuric acid plant near Solwezi, in Zambia, which employs the ISASMELT smelting technology and was commissioned in 2015 at an estimated capital cost of US\$900 million, was used as a reference project for the capital cost estimates for both the copper smelter and the acid plant. This study concluded that the projected tonnage of copper concentrates production in Botswana would not justify the establishment of a smelter and acid plant on its own, and that a lower tax rate would vastly improve the project economics. There are other studies that would need to be carried out at a greater level of detail at the prefeasibility stage to further understand the viability of this project. These include:

> Further investigations into the ability of the copper projects under development to increase their total production to about $0.5 \mathrm{Mt}$ of concentrate per annum

> A study of the likelihood of concentrate imports from existing or planned projects in the region to augment local concentrate production so that the copper smelter can be operated at near full capacity of $0.5 \mathrm{Mt} / \mathrm{a}$ concentrate

> A market study to establish the likely revenue and offtake quantities of sulphuric acid, as revenue from the sale of acid is significant in the smelter project economics,

> Initial discussion with the Botswana government regarding a tax agreement for the project to pay tax at the rate for manufacturing businesses, which is currently set at $15 \%$

> A preliminary investigation into whether the power parastatal would be in a position to negotiate charges for power that would not hurt the sustainability of this project.

\section{References}

Barlows, A., Partington, P., Sakala, J., and Mascrenhas, P.H. 2012. ISAsmelt at Mufulira-increased flexibility on the Zambian copper belt. Metals and Materials Processing in a Clean Environment. Volume 1. Sustainable Non-ferrous Smelting in the 21st Century. Kongoli, F. (ed.). Flogen Star OUTREACH, MontRoyal, Quebec, Canada.

Boulamanti, A. and Moya, J.A. 2016. Production costs of the non-ferrous metals in the EU and other countries: Copper and zinc. Resources Policy, vol. 49. pp. 112-118.

ConNeluy, D. 2017. Copper smelting technology trends. https://www.linkedin.com/ pulse/copper-smelting-technology-trends-damian-connelly/ [accessed 14 June 2018].

CRADLE ARC PLC. 2018. A significant producing mine in North Eastern Botswana http://cradlearc.com/projects/mowana-copper-project/ [accessed 19 October 2018].
Cupric Canyon. 2018. Zone 5 development. https://www.cupriccanyon.com/ development-exploration/zone-5-development [accessed 23 September 2018].

Economic ReSEARCH InSTITUTE. 2017. Copper market study. ERI, Ulaanbaatar.

FirST QuANTum Minerals LtD. 2012. Our record speaks for itself. https://s1.q4cdn. com/857957299/files/doc_presentations/Presentation\%20-\%20December\%20 -\%20FINAL.pdf

Foskor Pty Ltd. 2018. http://www.foskor.co.za/SitePages/Documents/Product\%20 Prices.aspx [accessed 11 October 2018].

GLASENBERG, E. 2018. Value over volume: delivered. Now the pivot to growth? Proceedings of the Bank of America Merrill Lynch 2018 Global Metals, Mining and Steel Conference. Glencore. https://www.glencore.com/dam/jcr:ed473251f7ea-4ae7-ad5b-8bf2d0a6900c/20180515\%20GLEN\%202018\%20BAML\%20 presentation\%20FINAL.pdf

International Copper Study Group. 2018. The World Copper Factbook 2017. ICSG, Lisbon, Portugal.

Kansanshi Mining PLc. 2018. Sulphuric acid on the web. http://www.sulphuric-acid. com/sulphuric-acid-on-the-web/acid\%20plants/Kansanshi-Mining-Smelter.htm [accessed 13 October 2018].

Kojo, I.V., Scheidema, M.N., and Reuter, M.A. 2015. Primary copper smelting impact. Proceedings of the European Metallurgical Conference 2015. Vol. 1. GDMB Gesellschaft der Metallurgen und Bergleute, Clausthal-Zellerfeld, Germany. pp. 77-94.

LEE, E.Y. and SHIN, Y.S. 2018. Copper and its electrifying future. DBS Asian Insights Sector Briefing 61. Asian Insights Office: DBS Bank.

LeUnG, J. 2018. China's spot TC/RCs for imported copper conc rises to $\$ 84-\$ 90$ / mt; stalemate persists. https://www.spglobal.com/platts/en/market-insights/ videos/market-movers-asia/100818-asia-commodites-week-ahead [accessed 10 October 2018].

Mod Resources. 2018. T3 Pre-feasibility study confirms robust long life copper mine. ASX announcement. https://www.asx.com.au/asxpdf/20180131/ pdf/43r5bxy6b4p5yq.pdf

Mulunda, C., Musonda, E.K., and LuwayA, E. 2015. Review of value addition to raw copper in Zambia. International Journal of Science and Research. https://www. ijsr.net/archive/v6i7/ART20175117.pdf

NEw Boliden. 2017. Metals and innovation for the future. Annual report 2016. https://vp217.alertir.com/afw/files/press/boliden/201703089998-1.pdf

Roos, J. and De VRIEs, D. 2005. Mufulira smelter upgrade 'industry' smelting on the Zambian Copperbelt. Mupani Copper Mines, Kitwe, Zambia.

SöDERSTRÖM, U. 2008. Copper smelter revenue stream. Capital Markets Day. New Boliden. https://www.boliden.com/globalassets/investor-relations/reports-andpresentations/capital-markets-day/2008/cmd/13-copper-smelters-revenuestream-ulf-soderstrom-president-ba-market.pdf

WoRLD BANK. 2011. What is the potential for more copper fabrication in Zambia? The World Bank, Finance \& Private Sector Development Unit, Africa Region, Washington, D.C.

WORLD BANK. 2012. Afghanistan resource corridor development: strategic input on the development of the Aynak copper mine - Final report on Aynak project. Washington, D.C.

World BANK. 2018. Commodity markets outlook: Oil exporters: Policies and challenges. Washington, D.C.

Zhang, L., CAI, Z., YAng, J., Yuan, Z., and Chena, Y. 2015 The future of copper in China-A perspective based on analysis of copper flows and stocks. Science of the Total Environment, vol. 536. pp. 142-149. 